\title{
Discussion and Improvement in Your Teaching
}

\author{
Zhaoye $\mathrm{Li}^{1 *}$ \\ Tianjin University of Technology and Education \\ Tianjin University of Technology and Education \\ Tianjin, China \\ zhaoyeqingdao@163.com \\ Zhaojun Xue \\ Tianjin University of Technology and Education \\ Tianjin University of Technology and Education \\ Tianjin, China
}

\author{
Shixin $\mathrm{Li}^{2}$ \\ Tianjin University of Technology and Education \\ Tianjin University of Technology and Education \\ Tianjin, China
}

\begin{abstract}
Questions and answers in teaching are elaborated carefully in this paper. Improving teaching methods, adding practice session, and making all students happy, these ways can obtain obvious effects.

Keywords—practice training; career guidance; competitive

\section{INTRODUCTION}

In order to train professional students in modern society, our teachers in every university must change their methods and attitudes in their classes. With fast increasing of graduates every year, opportunities of good offers in work become less and less. Certainly, disappointment, nervousness and inexertion often come out in our students. As a responsible teacher, he should help students in studying their lessons well.
\end{abstract}

\section{QUESTIONS IN MODERN EDUCATION IN OUR UNIVERSITIES}

\section{A. Simple Teaching Methods in Classes}

Though more and more teachers have paid more attention to their lessons [1], their methods in teaching are still too simple. For example, they teach their PowerPoints (PPT) in classes according to old plans. And students are listening carefully. With time becoming long, some students don't like this method and study this lesson. Then the students study nothing and become weaker and weaker in their learning abilities. Negative moods lead to disappointed learning motivation and bad grades in their lessons. When their senior years come, chances of different good offers will be lost from their special fields. What a pity. As a qualified and responsible teacher in our universities, improving teaching methods and qualities become more and more important.

\section{B. Chances of Practical Training Become Little.}

The template is used to format your paper and style the text. All margins, column widths, line spaces, and text fonts are prescribed; please do not alter them. You may note peculiarities. For example, the head margin in this template measures proportionately more than is customary. This measurement and others are deliberate, using specifications that anticipate your paper as one part of the entire proceedings, and not as an independent document. Please do not revise any of the current designations.

Just like mentioned above, good offers will be not given ineffective graduate. Most undergraduates in modern society can't find suitable offers because of weak practical training ability [2]. Especially, some of them can't operate machines though they have gotten higher scores than others. Besides, different competitions in kinds of fields need competitive students more and more. It is important to strengthen their practical training ability. However, according to our plans and different demands in current teaching, it is little time used in practical training. Little time used in practical training leads to weak manipulative abilities of operation in students. Weak ability causes few offers. Vicious circle hurts our education, which results in harmful effect.

\section{Old Details Influencing Efficiency}

Most of universities in our country want to get high percent in graduation. So lessons about careers guidance are arranged in certain session. However, teachers in this lesson usually talk about details in applying for a job. He will be not tell students how to possess ability in a successful apply. The guider is only familiar with his special field. He can't tell all guidance in specific 
profession ability. If a student studies according an old plan, he will be a person being good at writing his resume. In the process of career guidance, theory is not satisfied with practice. This lack influences employment ratio heavily.

\section{Some Lack of Relations Between Teaching and Careers Guidance [3-6]}

With the developing of computer, PPT has been widely used in classroom teaching. It is efficiency when using PPT in our teaching. Certainly, the theory in our classroom will be not changed anyway you apply PPT or not. However, the cases in our teaching have been not changed for a long years. Some details in your course may be not satisfied with current job applying. Some details can be deleted in our course. Even if a student getting high scores in his course, his work can't be praised by his boss.

\section{ANSWERS TO SOLVE QUESTIONS IN CURRENT TEACHING}

\section{A. Individuality Education Replacing Simple Education}

With the development of economy, graduates from every university should be satisfied with commands of jobs. In some special careers and majors, companies have been united with universities. This can cover the shortage of theory teaching. Especially in electric, car, machines, and so on. That is because the components in these careers are upgrading in every year. Some components can be replaced by new products per a few years. For example, speed of integration level in circuits is according with series per ten years. Besides, model for jointly running a school can make our teachers know how to train our students according with commands of society. This is valuable. To cooperators, his students as workers can adapt operating post as early as possible. Nowadays, a majority of courses have been not united with companies in teaching. When efficiency and advantages are shown in joint school, improving will turn out in our teaching. For example, major of course can be stated in our class. Fashionable components can be introduced into our class. This can make up the lack of theory teaching.

\section{B. Units Division of All Students into Different Components}

Individualized education is always mentioned in these years. Study ability is different from each other because of family factor, surrounding factor, economy, and so on. Some students may be good at learning. In the reverse, some students don't know how to use time efficaciously. If they study together in the same class, schedule will become slower and slower. Division of all students into different groups can help them improve efficiency in study course. At the same time, our teachers can guide different students according to their individual problems. Maybe some students want to develop some other interests, our teachers can help them become excellent job hunter. Improved efficiency can enhance teaching result. It should be advocated and adopt.

\section{Cooperation and Team are Efficiency}

New forms of education ask our teachers must stay with our students happily, comfortably and actively. Everyone wants to study and live happily. Happy mood can help them study fast. Besides, the wondering students may ask his teachers about his uncertain knowledge. In addition, cooperation is important for students in nowadays. Teachers can help students divide into different teams. Partners in the same team can help each other in learning theory and practice training. In the process of cooperation, individual thinking ability and practice training can be improved. When they graduate from their school, they will adapt their work environment and teams quickly.

\section{Kinds of Competitions can Help Students Improve Their Ability}

Lives in school are different from that in society. Most of students don't know how to be competitive in their campus life. Our teachers can encourage students to participate in different competitions. For example, students studying electrics need to participate in electric competition to improve their ability in circuits. When they design circuits by themselves, their innovation ability can be enhanced fast.

\section{SUMMARY}

In this research, reform in education was discussed carefully. Questions about teaching in modern university were stated and discussed. Besides, answers to solve these problems can be also provided. Happy mood, cooperation, individual mind can help students be successful job seeker.

\section{ACKNOWLEDGMENT}

This research was financially supported by the Tianjin municipal education commission project and specialty construction funds, Tianjin university of technology and education research and development fund funded project (No. KW14-70), and Tianjin higher school science and technology development fund project (No. JWK1619).

Tianjin municipal education commission project and specialty construction funds, Tianjin university of technology and education research and development fund funded project (No. KW14-70), and Tianjin higher school science and technology development fund project (No. JWK1619)). 


\section{REFERENCES}

[1] Yunhong Chen, Yumei Kang. Research on the Teaching of the Course Building Construction, Journal of Higher Education, vol. 1, pp 109-111, 2017.

[2] Hua Peng. White, The Attentive Problems in the Teaching Management in Colleges and Universities in the New Period, Occupation Education, vol. 1, pp 24, 2017.

[3] Qiang Zhang, Liping Huang, Debao Wu, Baolin Zhao, Bo Ma. Analysis of Employment Guidance in Higher Vocational Colleges, University Education, vol. 1 , pp 172-173, 2017.

[4] Chunmei Chen. Research on Employment Guidance of British and American Undergraduates, Ournal of World Education, vol. 6, pp 32-40, 2017.

[5] Huixiang Lian. Strengthen the Employment Groups to Help Improve the Level of Guidance Services, Guangdong vocational and technical education and research, vol. 1, pp 86-89, 2017.

[6] Tayu Niu. Reflection and Innovation of Educational Reform from the Perspective of Employment Guidance in Colleges and Universities, Survey of Education, vol. 6, pp 56-57, 2017. 